\title{
200 éve született Semmelweis Ignác, a modern perinatológia magyar ikonja
}

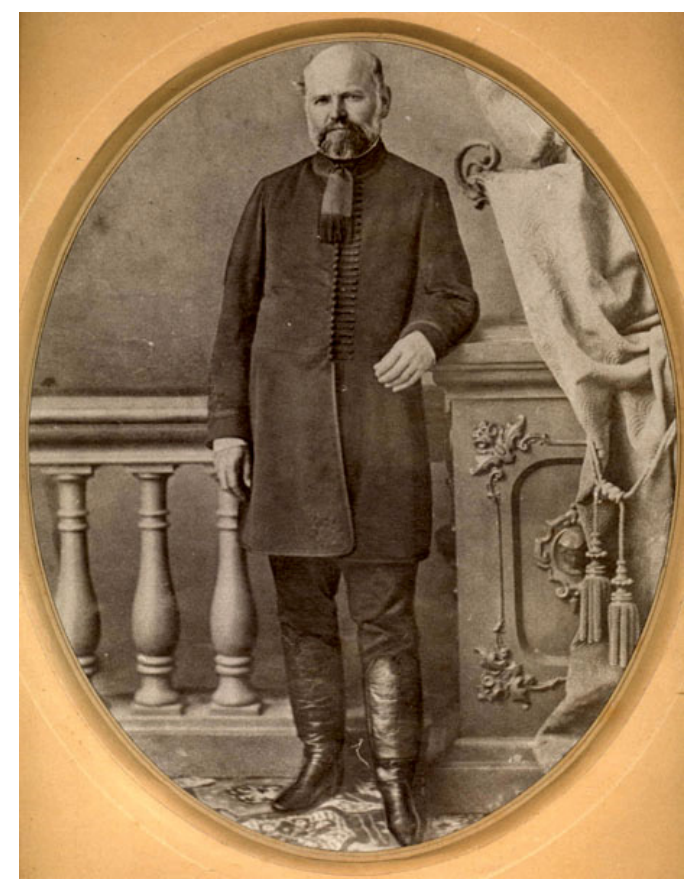

Semmelweis Ignác (1818-1865) Budán, 1818. július l-jén született, és a bécsi orvosi egyetemen végzett. Végzése után az egyik bécsi szülészeti klinikán kapott állást, és fiatal tanársegédként hatalmas tömegú statisztikai adatanyag hosszú idősorainak összehasonlító elemzése révén 1847 tavaszán arra a felfedezésre jutott, hogy a gyermekágyi láz sebfertőzés következménye. A szülőnők vizsgálata során az orvosok és orvostanhallgatók kezéről „bomló állati szerves anyag” kerül a szülőutakba, és az onnan felszívódik. Felfedezésében a legtekintélyesebb szülészek is kételkedtek, állását megszüntették, és az egyetemi magántanári képesítés megszerzése után csalódottan hazatért szülőföldjére, majd a pesti Szent Rókus Kórház szülészeti osztályáról került 1855-ben az egyetemi tanszék élére.

A Szülészeti Klinika az egyetem Pestre költözésekor a Hatvani és Újvilág (ma: Kossuth Lajos és Semmelweis) utca sarkán állt, az egykori jezsuita rendház második emeletén foglalt helyet, és az 1850-es években egy háromágyas, egyablakos szülőszobából és három gyermekágyas szobából állt, összesen 26 ággyal. A Klinika Semmelweis ismételt kérésére került át 1859 tavaszán a sebészeti részleggel együtt az Országúti (ma: Múzeum körúti) „Kunewalder terményház” Hild József által 1838-ban emelt épületének második emeletére. Külön tanterem nem lévén, Semmelweis olykor a folyosókon tartotta előadásait a mintegy 200 fónyi hallgatóságnak: háromnegyed részben bábajelölteknek, s azonkívül főlleg sebészhallgatóknak - minthogy az orvosnövendékeknek nem volt kötelező a szülészet hallgatása. Az elméleti szülészetet Semmelweis többnyire magyarul, a gyakorlati szülészetet magyarul és németül adta elő.

Nagy jelentőségű felfedezésének ismertetésére csak barátai hosszas unszolására vállalkozott a Pest-Budai Orvosegyesület 1858. január 2-i tudományos ülésén tartott, majd még további három ülésen elhangzott - és folytatásokban az Orvosi Hetilapban is közzétett - elöadásával. Végül 1860 októberében megjelent németül (magyar fordításban csak 1906-ban) több mint 500 oldalas főmúve „A gyermekágyi láz kóroktana, fogalma és megelőzése" címmel.

A könyvet külföldön a legjobb esetben hallgatás és közöny fogadta, de nagyobbrészt ellene foglaltak állást. Ezek után Semmelweis megírta híressé vált leveleit a legismertebb szülészprofesszoroknak, majd a szülészet öszszes tanárához fordult: könyve tartalmát röviden összefoglalva vitázik ellenfeleivel, és maró gúnnyal illeti a vele legélesebben szemben állókat. A levelek - hangvételük miatt - nem érték el ugyan tanításának széles körủ érvényesülését, de felébresztették az érdeklődést a gyermekágyi láz megelőzésének lehetősége iránt. A nyílt levelek írása közben Semmelweis kidolgozta a teendőket a láz megelőzésére, ami valójában a szülészeti asepsis követelményeinek első hivatalos leírása volt.

Küzdelmei megviselték idegrendszerét, majd a pesti orvosi kar kezdeményezésére Bécsbe szállították, és elmegyógyintézetbe zárták. Ott halt meg 1865. augusztus 13-án.

A halálhírt gyászkeretben az Orvosi Hetilap az 1865. augusztus 20-án megjelent 34. számában közölte: „... Béke a jeles búvár, a tudományos szakférfiu s az igaz szivü honpolgár hamvaira!”

Semmelweis azonban még sokáig nem került be a szellemi panteonba. Halálát döbbenetes hallgatás követte. A síri csendet csak itt-ott szakította meg egy-egy kérészéletû́ pletykavirág, megbízhatatlan hallomás. Még a legautentikusabb személyek is hallgattak.

A bécsi napilapok pár szavas hírrel adták tudtul Semmelweis halálát és temetését. Kettő közülük, például a bécsi Fremdenblatt azt közölte, hogy Döblingben halt meg és temették el. Ezt több életrajzíró is átvette! A Wiener Medizinische Presse az 1865. augusztus 20-i, a British Medical Journal az augusztus 26-i, a Wiener Medizinische Zeitung a szeptember 15-i számában alig 1-2 
sorban emlékezett meg a halálesetról. A külföldi folyóiratok közül a Wiener Medizinische Wochenschrift foglalkozott a legtöbbet Semmelweis elhunytával. Az 1865. évi 65. számában a következőket írja: „Semmelweis tanár tegnap áldozatul esett betegségének. Most csak néhány szóval jelentjük ezt az elszomoritó hirt. Ha nem is tudtuk helyeselni azt a módot, amellyel az elhunyt az utolsó években kartársaival szemben viselkedett, mindig igazságot igyekeztünk szolgáltatni törekvésének és munkásságának.”

A pesti Gyógyászat, amely az 1860-as évek második felében éles harcban állt a Markusovszky Lajos által 1857 ben alapított Orvosi Hetilappal és köreivel, köztük Semmelweisszel is, 1865. augusztus 5-én a következőket írta: „Sajnálatos részuéttel írjuk, hogy Semmelweis egyetemi tanárt veszélyes agybántalom érte, mely miatt ö egyik bécsi gyógyintézetbe vitetett. Beteges izgatagságának régóta adta jeleit, s a párt, mely ôt sajátjának vallá, a gyógytörekvés belyett sokszor a szenvedélyes kitörésekig csigázta izgatagságát.” A „beteges izgatagság” azokra a korábbi orvosegyesületi vitákra utal, amelyeken Semmelweis Markusovszkyval együtt igen harciasan viselkedett. Két héttel később ugyanezen lap, sajnálatot sem színlelve, egyetlen mondatban közölte, hogy Semmelweis „állitólag pyaemia következtében” meghalt $(1865,590$. oldal). Ez a megállapítás lehet tárgyilagos ténymegállapítás, de inkább annak az ironikus kifejezése, hogy a vérmérgezést az elmebaj elkendőzésének tartották. Egyébként a vérmérgezés még Markusovszy Lajost is váratlanul érte, mint az 1865. augusztus 20-án az Orvosi Hetilapban, az 551. és 552. hasábban megjelent hosszú és meleg hangú nekrológjából is kiderül.

A pesti napilapok feltúnően röviden, egymondatos napihírben közölték a halál hírét, egyedül a Pester Lloyd szánt rá húsz sort (1865. augusztus 15., 187. sz.). Megmagyarázhatatlan a Pesti Napló szúkszavúsága, hiszen ez az újság sokat foglalkozott az ország egészségügyi problémáival, és ugyanakkor egy fiatal kórházi sebészorvos haláláról hosszú megemlékezést közölt, Semmelweisröl pedig csak annyit, hogy: „Semmelweis tudor, pesti egyetemi tanár, mint magánúton értesültünk, tegnap reggel Bécsben meghalt. Nyugodjanak békén porai. (1865. angusztus 15.) ” Ső́t a Családi Kör folyóirat odáig ment, hogy „Egy örült halála” címmel ízléstelen cikket közölt, és kitalált történettel próbálta megnyerni olvasóit.

Két héttel Semmelweis halála után Pozsonyban a Balassa János elnökletével zajló orvosi „Magyar Orvosok és Természetvizsgálók” XI. vándorgyưlése nem emlékezett meg Semmelweis haláláról, holott a szervezeti szabályzat is előírta, hogy az időközben elhunyt tagokról emlékezést kell tartani.

A vissza- és megemlékezésekre évtizedeket kellett várni. Az ország és az egész világ ma már kétségtelenül fejet hajt a nagy magyar orvos munkássága előtt. Születésének 200. évfordulója kiváló alkalom világszerte a megemlékezésekre. Az Orvosi Hetilap a Semmelweis Egyetemmel közösen 2018. június 30 -án, születésének előnapján tartja közös ünnepi tudományos ülését, a 2018. július 1-jei 26. számunkat pedig a nagy magyar orvos emlékének szenteljük.

A 2018-as év jó alkalom egy másik nagy magyar orvos, Markusovszky Lajos (1815-1893) halála 125. évfordulójának megünneplésére is. Markusovszky és Semmelweis barátsága Bécsben indult, és az 1840 -es évek közepére tehető. A köztük kialakult megbecsülés és ragaszkodás Markusovszky részéről Semmelweis halála után is folytatódott, részt vett nemcsak a schmelzi temetésen 1865-ben, hanem az 1891-es kihantolásra elkísérte Semmelweis özvegyét, és szerepe volt a földi maradványok itthoni méltó fogadtatásának megszervezésében is. Még életükben Markusovszky sokat tett Semmelweis felfedezésének népszerüsítéséért és elfogadtatásáért, sokat harcoltak együtt az orvosegyesületi rendezvényeken a gyermekágyi láz etiológiáját és megelőzésének lehetőségét tagadó kollégákkal. Markusovszky kezdeményezte, hogy az általa 1857-ben alapított Orvosi Hetilapban is minél többet publikáljon a barátja, és ennek a biztatásnak meg is lett a gyümölcse, Semmelweis írásai elsősorban a Hetilapban jelentek meg.

Véletlenül úgy hozta a sorsom, hogy nemcsak a pesti szülészeti klinikán voltam Semmelweis nyolcadik tanszékvezetőii utóda, hanem az Orvosi Hetilap főszerkesztői székében is a nyolcadik utóda vagyok Markusovszky Lajos alapító főszerkesztőnek. Ez a megtisztelő összeesés nemcsak felemelő érzéssel tölt el, hanem erkölcsi kötelességet is jelent, hogy a nagy elődök emlékét mindkettőjük szakmai utódaként próbáljam méltó módon szolgálni. Ennek igyekszem megfelelni a Markusovszky Lajos által létrehozott Orvosi Hetilap általam szerkesztett 159. évfolyamának 26. számával is, hogy őszintén tisztelegjünk Semmelweis Ignác emberi nagysága előtt.

Papp Zoltán dr. fószerkeszto"

\section{„Tiszta és nagy dolgokhoz csak tiszta és egyenes úton lehet eljutni." (Tamási Áron)}

